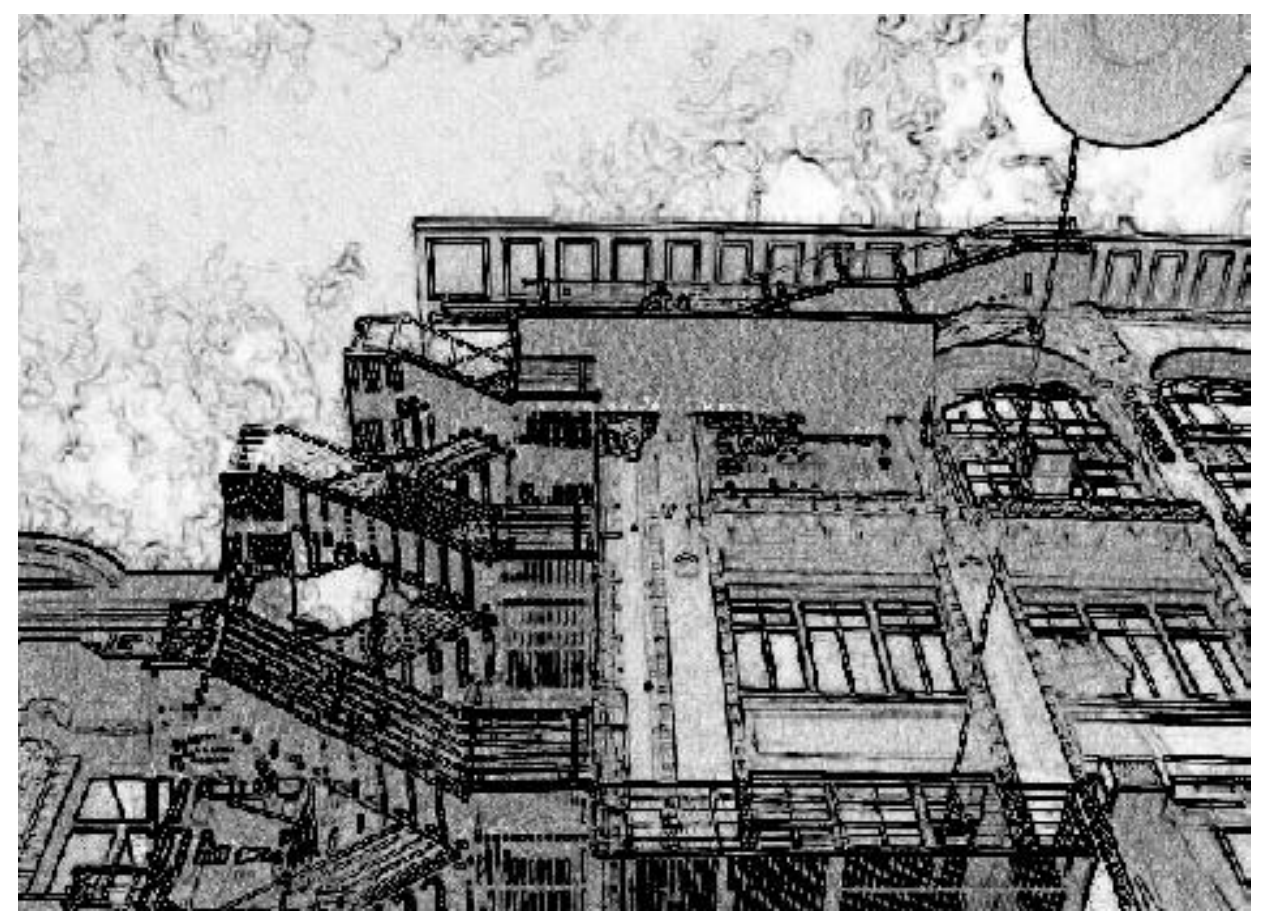

\title{
Will FTAA Bring Income Convergence?
}

Cecilia Maya Ochoa

Juan Manuel Restrepo Puerta

Ecos de Economía No. 17. Medellín, octubre 2003, pp. 31 - 49 


\section{Cecilia Maya Ochoa* \\ Juan Manuel Restrepo Puerta**}

-Abstract. By the beginning of year 2006, the Free Trade Area of the Americas, FTAA, will be launched. Mixed expectations and concerns about its effects on the individual economies have grown in the area since this process started in December, 1994. This paper aims to discuss a particular expectation -or concern- which is: Will this liberalization of the Americas contribute to increase or to decrease the huge gap in per capita income between the industrialized economies of the North, -Canada and the U.S.- and the other thirty-two countries? Based on the analysis of empirical evidence on current trade areas in the region, we conclude that even in the case of equal trade, where the agreement manages to conciliate the interests of developed and less developed countries, income convergence will, probably, not be one of the outcomes of this liberalization. The lack of symmetry in an area which gathers countries at very different stages of development, an asymmetry much more pronounced in the FTAA because it includes the largest economy in the world, prevent us from expecting income convergence even if this trade area becomes a successful one.

Keywords: FTAA, Free Trade Area of the Americas, Income Convergence, Free Trade.

-Resumen. A comienzos del 2006 se espera el lanzamiento del ALCA. Muchas inquietudes existen en torno a los posibles efectos que la conformación de esta área de libre comercio tendrá sobre las economías de los países integrantes. Este artículo analiza una de estas inquietudes la cual se refiere a si esta integración de las Americas contribuirá a cerrar la brecha en el ingreso per capita de las naciones industrializadas del norte -Canadá y Estados Unidosy las otras treinta y dos naciones $\mathrm{o}$, por el contrario, profundizará dicha brecha? Con base en la evidencia empírica de otras zonas de libre comercio de la región, se concluye que, aún en el caso de que en el tratado se logren conciliar los intereses de los países desarrollados y los no desarrollados para un comercio justo, la convergencia del ingreso per cápita no será, probablemente, uno de los resultados de esta integración. La asimetría existente en esta región, más aguda en el caso del ALCA por el hecho de que esta área comprende la más grande economía del mundo, impide esperar que se logre convergencia aunque el área resulte exitosa.

Palabras Clave: ALCA, Tratado de Libre Comercio de las Américas, Convergencia del Ingreso, Libre Comercio.

* Ph.D. Candidate in International Economics and Finance, Brandeis University, USA. Docente. Departamento de Finanzas. Universidad EAFIT. (cmaya@eafit.edu.co)

**Estudiante de décimo semestre de Economía. Universidad EAFIT. (jrestr24@eafit.edu.co) 


\title{
Will FTAA Bring Income Convergence?
}

\author{
Cecilia Maya Ochoa ${ }^{1}$ \\ Juan Manuel Restrepo Puerta ${ }^{2}$
}

\section{Introduction.}

$\mathbf{B}_{y}$ the beginning of year 2006, the Free Trade Area of the Americas, FTAA, will be launched. This trade area will congregate thirty-four countries in North America, Latin America, and the Caribbean. Mixed expectations and concerns have emerged about its effects on the individual economies since this process started in December 1994. This paper aims to discuss a particular expectation -or concern- which is: Will this liberalization of the Americas contribute to increase or to decrease the huge gap in per capita income between the industrialized economies of the North, Canada and the U.S., and the other thirty-two countries?

Back in 1969, Arghiri Emmanuel wrote an essay under the controversial title of "Unequal Exchange: A Study of the Imperialism of Trade" where he accuses trade of contributing to widen the income gap among rich and poor nations. Later, in 1993, Dan Ben-David published "Equalizing exchange: Trade Liberalization and Income Convergence" and finds evidence that trade actually contributes to reduce income disparity among nations. Who is right? Based on the empirical evidence found in this study we argue that both may be right!

In this paper, we perform a study similar to the one conducted by Ben-David (1993a) on the EEC. We analyze whether the establishment of the ALALC - ALADI, the Andean Community of Nations (CAN) -Andean henceforth-, the Southern Common Market (Mercosur), and the North America Free Trade Area (NAFTA) have contributed 
to the convergence of per capita income within these areas. These results can shed some light on what the FTAA members may expect about per capita income convergence once this area takes off.

\section{What Does Evidence Have to Say on Trade and Income Convergence?}

Traditional neoclassical growth literature, i.e. the Solow's growth model (1956), predicts that in the long-run economies will converge to the same steady-state path provided that they have identical technologies ${ }^{1}$, population growth rate, and savings rate. Furthermore, the model predicts that the higher the savings rate, the richer the country, and the higher the population growth rate, the poorer the country.

Mankiw, Romer, and Weil (1992) argue that, based on the Solow model, convergence should not be expected since countries usually exhibit different savings and population growth rates, hence, they reach different steady state paths. Convergence can be expected only if differences between savings and population growth rates are controlled for as they do in their augmented Solow model where they also include accumulation of human and physical capital. They find convergence at roughly the rate that the model predicts for the OECD countries but could not find a tendency for poor countries to grow faster on average than rich countries which is required for convergence.

A contemporary study by Barro and Sala-i-Martin (1992) finds convergence for a sample of ninety eight countries from 1960 to 1985, This study is based on the standard neoclassical growth model with exogenous technological progress and a closed economy. They also find that when technologies are the same, introducing a global capital market increases convergence for output but slows down income convergence.

In a previous study, Baumol (1986) finds evidence of convergence on the average rate of productivity growth among sixteen industrialized market economies in the period 1870-1979. He also performes a more comprehensive study using data on output per capita covering the period 1950-1980 for seventy-two countries, and concludes that the same sixteen countries analyzed before show convergence, as well as a second group of planned economies, even a third one comprising intermediate economies, although convergence in these last two groups is not so pronounced. The

1 The Solow model assumes a standard neoclassical production function with decreasing returns to capital. 
remaining countries do not show convergence. Based on these findings he suggests that there is more than one convergence group, perhaps three of them. He also concludes that "the poorer less developed countries are still largely barred from the homogenization process" (p.1080).

In a later comment, De Long (1988) criticizes Baumol's findings based on the sample selection of his study. Baumol uses an ex post sample of countries that are now rich and developed ${ }^{2}$. Those countries that have not converged are excluded from the sample because of their resulting present poverty, thus, convergence is guaranteed in Baumol's regression. De Long uses an unbiased sample of countries covering the same period as Baumol and finds that the long-run data do not show convergence, furthermore, the forces making for convergence even among industrial nations appear little stronger than the forces making for divergence, thus the relative income gap between rich and poor nations may tend to widen. To this study, Baumol and Wolff reply showing new results using the 1950-1980 data for seventy-two countries. After performing many tests they conclude that "for perhaps the top fifteen countries convergence has been marked and unambiguous, with a mild recent retreat. All countries together, excluding less developed countries, have also shown some convergence". Baumol and Wolff (1988, p.1159)

All these previous papers analyze convergence in what Slaughter (1997) calls a "Solow world" in which countries exist independently from one another, ignoring international linkages ${ }^{3}$. However, what may drive convergence among countries is their exchange of goods, factors, and technologies. According to the factor price equalization theorem (FPE), when countries with similar technologies trade, the relative prices of goods converge and this causes the returns to the different factors of production to converge as well (Samuelson, 1948, 1949). In addition, international flows of factors and technology can cause convergence of factor prices as well.

Recognizing this link between trade and income convergence, Ben-David (1993a) performs a study on the European Economic Community -EEC- to test if liberalization contributed to cause income convergence in this area. He chooses the EEC because after liberalization took place, there was "significantly increased trade while exhibiting negligible improvements in factor flows", meaning that if income convergence occurred,

2 The data for Baumol's study corresponds to a group of countries previously selected by Angus Maddison for his study on the Phases of Capitalist Development. Oxford: Oxford University Press, 1982.

3 Only Barro and Sala-i-Martin (1992) includes international capital mobility in a limited way. 
it was due to trade, not to factor mobility. The other reason for choosing the EEC is to eliminate the problem of sample selection that may affect the determination of income convergence/divergence outcomes. The study compares trade and income before and after the liberalization and finds evidence that income converged as a result of increased trade.

In a later study Ben-David finds that, from 1960 to 1989, groups of relatively wealthy countries which trade significantly among themselves also tend to display significant income convergence (Ben-David, 1996). In an additional study on this subject, Sachs and Warner classify each country in 1970 as either "open" or "closed" to international trade. From 1970 to 1989 they find a tendency to converge only within the group of open countries, meaning that "the convergence club is the club of economies linked together by international trade" (Sachs and Warner, 1995, p.41).

Slaughter (1997) considers that these last three papers make an important addition to the literature on per capita income convergence by explicitly testing for the role of international trade. However, he criticizes them because their tests aim to find income convergence among countries which are somehow linked by trade and then infer that trade caused convergence. None of these studies explain causality, that is, how trade may cause income convergence. The same Slaughter recognizes in both of his studies on this subject that more work needs to be done in this sense (Slaughter, 1997, 1998) not without mentioning three possible channels through which trade may affect income convergence. These channels are, in the first place, factor price equalization (FPE), rather its dynamic analogue, factor price convergence $(\mathrm{FPC})^{4}$; a second channel may be international flows of technology which change countries' factor prices, and per capita income in consequence; finally, a third channel may be trade in capital goods which affects directly a country's per capita income through its endowment of factor quantities.

The other critique to Ben-David's and Sachs and Warner's studies is that they compare groups of countries only during the period in which the trading groups actually trade extensively. Particularly in the case of Ben-David (1993a) "he makes only limited attempts to compare post-liberalization convergence either to preliberalization experience of liberalizers or to a set of control countries" (Slaughter, 1998).

4 The theorem of factor price convergence (FPC) was defined by Edward E. Leamer in the following way: "When two countries eliminate their mutual trade barriers, product price equalization eliminates factor-price differences" (Leamer, 1995, p.7), cited by Slaughter (1997, p.195). 
Slaughter (1998) builds on these studies by identifying trade's effect on convergence by using a difference-in-differences approach applied to four episodes of trade liberalization: the European Economic Community (EEC), the European Free-Trade Area (EFTA), liberalization between the EEC and the EFTA, and the Kennedy-round liberalization of the GATT. His main empirical result is that trade liberalization did not trigger convergence in any of the four cases. If anything, trade seems to have caused income divergence.

The study we perform next has the same scope of these previous studies in the sense of examining evidence on income convergence within groups of countries participating in liberalization processes, without the pretension of proving causality between trade and income convergence, yet recognizing that this subject calls for additional research. We will study empirical evidence from six areas which are ANDEAN, MERCOSUR, NAFTA, ALALC - ALADI, North America, and The Americas ${ }^{5}$, using Ben-David's (1993a) methodology but taking into account Slaughter's critique in the sense of comparing performance before and after liberalization in each of these areas. Next, we provide some background on these free trade areas, followed by an explanation of the methodology of the study and a discussion of the empirical evidence.

\section{Americas' Liberalization: From Andean, Mercosur, and NAFTA Towards FTAA.}

\section{The Andean Community of Nations (Andean).}

It started as the Andean Pact in 1969 with the Cartagena Agreement. However, this free trade area was not really active until 1988 when it was reintroduced under the name of Andean Community of Nations. It congregates five countries, Bolivia, Colombia, Ecuador, Peru, and Venezuela. Peru is gradually becoming part of this area through a liberalization program. Tariffs have been eliminated for trade within this community, and a common external tariff has been established. According to the schedule, by 2005 there will be complete liberalization including free factor mobility.

The total population in the area is more than one hundred and fifteen millions, and its total GDP was around $\$ 287.3$ billions in $2001^{6}$. The average per capita income was $\$ 2,496$-in 2001- with a gap between the poorest country, Bolivia, with a per capita income of $\$ 941.2$ compared to Venezuela with a per capita income of $\$ 5,077.2$.

5 Andean, Mercosur, and NAFTA countries pooled.

6 Source: World Bank official website www.worldbank.org, Country at a Glance Tables 
Despite this gap, these countries can be considered similar in many aspects like geography -located in The Andes-, institutions, etnicity, and degree of education of their population. Finally, all of them are exporters of primary products, three of them being oil exporters: Colombia, Ecuador, and Venezuela.

\section{The North American Free Trade Agreement (NAFTA).}

NAFTA began in January 1, 1994. It comprises three countries, Canada, Mexico, and the United States. Since 1998, most of the trade between Canada and USA is free of tariffs, and in 2003 that will be the case for the trade between Canada and Mexico. A few provisions limiting trade on agricultural products remain, most of which will disappear by 2008 .

With a population of four hundred forty-four million people and a total GDP of more than $\$ 11,466$ billions in 2001, NAFTA is considered the largest free trade zone in the world. The average per capita income in the area was $\$ 27,670$ in 2001, commanded by large per capita incomes in the U.S. and Canada $-\$ 35,815$ and $\$ 21,845$, respectively-, compared to a relatively low Mexican per capita income of $\$ 6,215^{7}$. There are other asymmetries among these countries since Mexico is still considered a developing country where Canada and the U.S. are developed and, particularly, the U.S. is the largest economy in the world. USA mainly exports manufactured products; Canada exports both manufactured and primary products; and Mexico exports mainly primary products, oil being its main export.

\section{The Mercosur.}

It was created by the Asuncion Treaty in 1991 and started to operate in January 1, 1995 after the ratification of the Ouro Preto protocol. It congregates four countries, Argentina, Brazil, Paraguay, and Uruguay. Tariffs were eliminated in 1995 with the exception of some "sensible products" and a common external tariff has ruled since that date. Compared to NAFTA and Andean, this is the free trade zone that has achieved the lowest liberalization in terms of elimination of tariffs.

The Mercosur is a trade area of 219.1 million people, with a total GDP of $\$ 796.4$ billions -in 2001-. The average per capita income in the region is $\$ 3,635$ and only Paraguay's per capita income $-\$ 1,286$ in 2001 - is below the mean ${ }^{8}$. These countries present similar institutions and all of them are mainly exporters of primary products. Although they are at different stages in the industrialization process, especially if we

7 Source: World Bank official website www.worldbank.org, Country at a Glance Tables

8 Source: World Bank official website www.worldbank.org, Country at a Glance Tables 
compare Brazil to Paraguay, the level of development in terms of per capita income does not differ substantially.

\section{The Free Trade Area of the Americas. (FTAA).}

The ALADI is the first, most comprehensive, attempt of liberalization in the Americas. It continues a process initiated by the ALALC -Latin American Free Trade Association- in 1960. In 1980, the members of the ALALC signed the Montevideo Agreement to create the ALADI -Latin American Association for Liberalization- with the objective of promoting liberalization among the Latin American countries. Currently, it has twelve members ${ }^{9}$. Although it has not been successful in achieving all its goals, it certainly set the stage to an even more ambitious project: The FTAA. This Free Trade Area of the Americas will be the largest in the world and comprises the thirty-four countries in the region with the exception of Cuba. It will be launched in 2006 and its rules are based on the World Trade Organization (WTO) and NAFTA. As a particular characteristic, it includes a special treatment for the liberalization of the poorest economies in the region.

The previous background on the liberalization of the Americas will be important at the moment of discussing the empirical evidence on trade and income convergence within ALALC - ALADI, CAN, Mercosur, and NAFTA. It will also give some light in relation to the expectations we may have about income convergence in the Americas once the FTAA begins. Next, Section III examines the empirical evidence related to trade liberalization and income convergence in the Americas. Section IV and V search for explanations about the findings of section III by analyzing the evolution of trade flows from 1995 until 2000, and measuring per capita dispersion during the last four decades, respectively.

\section{Trade Liberalization and Income Convergence in the Americas.}

Following Ben-David's methodology yet incorporating Slaughter's (1998) critique, this section focuses on finding per capita income convergence within all six areas covered by this study: Andean, Mercosur, NAFTA, The Americas, ALALC ALADI, and North America. The objective is to determine if there was significant convergence/divergence as a consequence of liberalization by estimating the rate of convergence of each country's per capita income to the area's average per capita income, before and after liberalization took place.

9 ALADI members are Argentina, Bolivia, Brazil, Chile, Colombia, Ecuador, Mexico, Paraguay, Peru, Uruguay, and Venezuela. Cuba joined in August 26, 1999. 


\section{The Model.}

In Ben-David (1993a) he proposes the following model to estimate the rate of convergence of country i's per capita income to the group's average income level:

Let

$$
y_{, 11}-\bar{y}_{i}=\phi\left(\gamma_{i, i}-\bar{y}_{i}\right)
$$

where

$y_{i, t}=$ country i's log per capita income per year $t$

$\bar{y}_{1}=$ unweighted average of the log per capita incomes for the group in year t.

Letting $z_{i, t}=y_{i, t}-\bar{y}=$ the previous equation may be rewritten as

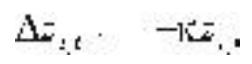

and $\Delta z_{i, t+1}=z_{i, t+1}-z_{i, t}$. The convergence coefficient $\mathrm{k}$, which is equal to $(1-\phi)$, represents the rate of convergence of country i's per capita income to the group's average income level. The larger the $\mathrm{k}$ - if positive -, the faster the convergence.

In order to estimate equation (2), a regression on a pooled time series and crosssection data is run. Since in this sample we are pooling many countries with different sizes -in terms of per capita income-, heteroskedasticity will be an issue to address. A simple OLS will not correct for heteroskedasticity, thus a feasible GLS is required in this case. The type of regression used to estimate this model is Cross-Section Weights which is a GLS that uses estimated cross-section residual variances. The estimation was iterated to convergence, which updates the weights and coefficients until they converge. Also, a White Heteroskedasticity Consistent Covariance was requested which generates a covariance matrix that is robust to general heteroskedasticity.

The hypothesis to be tested is that $\mathrm{k}$ is significantly different from zero, meaning that there is income convergence/divergence among the group of countries that are pooled. If $k$ is positive, there is convergence; if it is negative, income is diverging. We also compute the number of years required for the average differential to be cut in half (half-life, when $\mathrm{k}$ is positive) or doubled (when $\mathrm{k}$ is negative). Three regressions were run for each group of countries, the first one covering the entire sample period, a second one for the period before liberalization, and a third one for the period after liberalization took place ${ }^{10}$. Results are shown in Table 1.

10 For ALALC - ALADI this period corresponds to the entire sample. 


\begin{tabular}{|c|c|c|c|c|c|c|}
\hline \multicolumn{7}{|c|}{$\begin{array}{c}\text { Table } 1 \\
\text { CONHERGENCE COEFFICIENTS }\end{array}$} \\
\hline Free Trade Zone & $\mathbf{k}^{\prime}$ & $\begin{array}{c}\text { N } \\
\text { [vearsi }\end{array}$ & $\begin{array}{c}\text { t-stat } \\
\mathrm{Ho}: \mathrm{k}=0\end{array}$ & Half-tife & $\begin{array}{l}\text { Double- } \\
\text { life }\end{array}$ & $\mathbf{R}^{2}$ \\
\hline \multicolumn{7}{|l|}{ Andean } \\
\hline 1960-2000 & $\begin{array}{c}0,011 \\
0,005)\end{array}$ & 40 & $2.103^{\text {sh }}$ & 60.32 & & 0,018 \\
\hline $1960-1987$ & $\begin{array}{l}0,012 \\
0,007\end{array}$ & 27 & $1,876^{\circ}$ & 57.51 & & 0,021 \\
\hline $1988-2000$ & $\begin{array}{c}0,012 \\
(0,009)\end{array}$ & 13 & 1.344 & 57.51 & & 0,021 \\
\hline \multicolumn{7}{|l|}{ Hercosur } \\
\hline 1960-2000 & $\begin{array}{c}0.021 \\
(0.008)\end{array}$ & 40 & $2.694^{x-1}$ & 31.52 & & 0.042 \\
\hline $1960-1994$ & $\begin{array}{c}0,026 \\
10,009)\end{array}$ & 34 & $3,017^{\leftarrow}$ & 26,31 & & 0,060 \\
\hline $1995-2000$ & $\begin{array}{l}-0,011 \\
(0.021)\end{array}$ & 6 & -0.451 & & 66.36 & 0.009 \\
\hline \multicolumn{7}{|l|}{ NAFTA } \\
\hline $1960-2000$ & $\begin{array}{r}-0.003 \\
(0.003)\end{array}$ & 40 & -0.893 & & 246.52 & 0.007 \\
\hline $1960-1993$ & $\begin{array}{l}-0,003 \\
(0,004)\end{array}$ & 33 & -0.703 & & 249.52 & 0.007 \\
\hline $1994-2000$ & $\begin{array}{r}-0,003 \\
(0.005)\end{array}$ & 7 & -0.502 & & 251.21 & 0.011 \\
\hline \multicolumn{7}{|l|}{ The Americas } \\
\hline $1960-2000$ & $\begin{array}{c}0.003 \\
(0.003)\end{array}$ & 40 & 1.047 & 253.55 & & 0.0001 \\
\hline $1960-1980$ & $\begin{array}{c}0,009 \\
(0,003)\end{array}$ & 20 & $2.876^{\star}$ & 76.67 & & 0,029 \\
\hline $1981-2000$ & $\begin{array}{l}-0.007 \\
(0.004)\end{array}$ & 20 & $-1.861^{\star}$ & & 100.35 & 0.014 \\
\hline \multicolumn{7}{|l|}{ ALALC-ALADI } \\
\hline $1960-2000$ & $\begin{array}{c}0,009 \\
(0,004)\end{array}$ & 40 & $2.44^{* *}$ & 76.67 & & 0.01 \\
\hline \multicolumn{7}{|l|}{ North America } \\
\hline $1965-2000$ & $\begin{array}{r}-0.005 \\
(0,009)\end{array}$ & 36 & -0.512 & & 138.58 & 0.003 \\
\hline
\end{tabular}

"Significant al a $90 \%$ conliderice luval * Significant at a $95 \%$, standand Deviations are in parenthesis 
The ALALC - ALADI area shows income convergence with a significant positive $k$. Seventy-seven years will be required in this region for the income differential to be reduced in half ${ }^{11}$. Andean and Mercosur also exhibit income convergence after 1960 when their country members were part of the ALALC - ALADI. However, after liberalization, Andean continues converging while Mercosur starts to show divergence, although not significant in this case.

Once Canada and the U.S. - North America - are added to the pool to conform The Americas, this larger area exhibits significant income convergence before liberalization which turns into income divergence afterwards, with a negative significant $\mathrm{k}$ for the period 1980-2000. In one hundred years, this divergence will be doubled. On the other hand, NAFTA shows divergence before and after liberalization, as it is the case for North America, although in both cases $\mathrm{k}$ is not significant.

In terms of the relationship between trade and income convergence, the previous empirical evidence leads to contradictory conclusions. The results on the ALALC ALADI support Ben-David's hypothesis according to which trade helps to close the income gap instead of widening it. However, the evidence on The Americas supports the opposite hypothesis suggested by Emmanuel (1969) in the sense that income divergence may be the result of unequal exchange imposed by the "Imperialism of Trade". To this apparent contradiction, we argue that both may be right!.

The fact is that the inclusion of the U.S. on a pool generates divergence. That happens in The Americas, NAFTA, and North America. The explanation can be that the U.S. economy presents different characteristics than the rest of the Americas, the first one being that it is a much more developed country. Although Canada is also considered a developed country, its economy depends highly on exports of primary products as it is the case for the other countries in the Americas. The U.S., on the contrary, is mainly an exporter of manufactured products.

On the other hand, the ALALC-ALADI area shows convergence. The economies of these countries are more symmetric in the sense of being mainly exporters of agricultural products. They also have similar institutions and level of education. These results coincide with Ben-David's findings of convergence for the EEC which supports his hypothesis that trade may lead to income convergence. However, this EEC is an area where the economies also present much symmetry in terms of development, institutions, and production.

11 Half-life is calculated as $n$ (years) $=\ln (1 / 2) / \ln \mathrm{f}$. 
Finally, an alternative explanation to the fact that those areas including the U.S. diverge is that it may be a case of unequal trade, which is Emmanuel's argument. Current trade agreements in The Americas include clauses for free trade of manufactured products but limit exports of primary products, thus, these agreements favor exporters of the first ones. Even NAFTA, which is the deeper agreement in The Americas, has restrictions on exports of agricultural products which should end by 2008 .

\section{Liberalization and Trade Flows.}

Although trade flows data corresponding to the period $1995-2000^{12}$ show an increase in intra-area trade for Andean, Mercosur, and NAFTA in absolute terms, trade flows relative to GDP have remained stable. In the Andean area, total imports/GDP are around $1 \%$ in this period; they remain around $2.5 \%$ in Mercosur and 5.5\% in NAFTA. In this last one, total imports/GDP from the World went up from $12.4 \%$ in 1997 to $15.1 \%$ in 2000 , but it was not reflected in intra-area trade. The fact that the formation of these areas is not reflected on greater trade flows relative to GDP could explain why the coefficient of convergence/divergence is not significant there. Figures 1,2 , and 3 show intra-region, intra-Americas imports, and imports from the entire world, for Andean, Mercosur, and NAFTA.

12 For NAFTA the available data covers 1997 - 2000. 
Figure No. 1

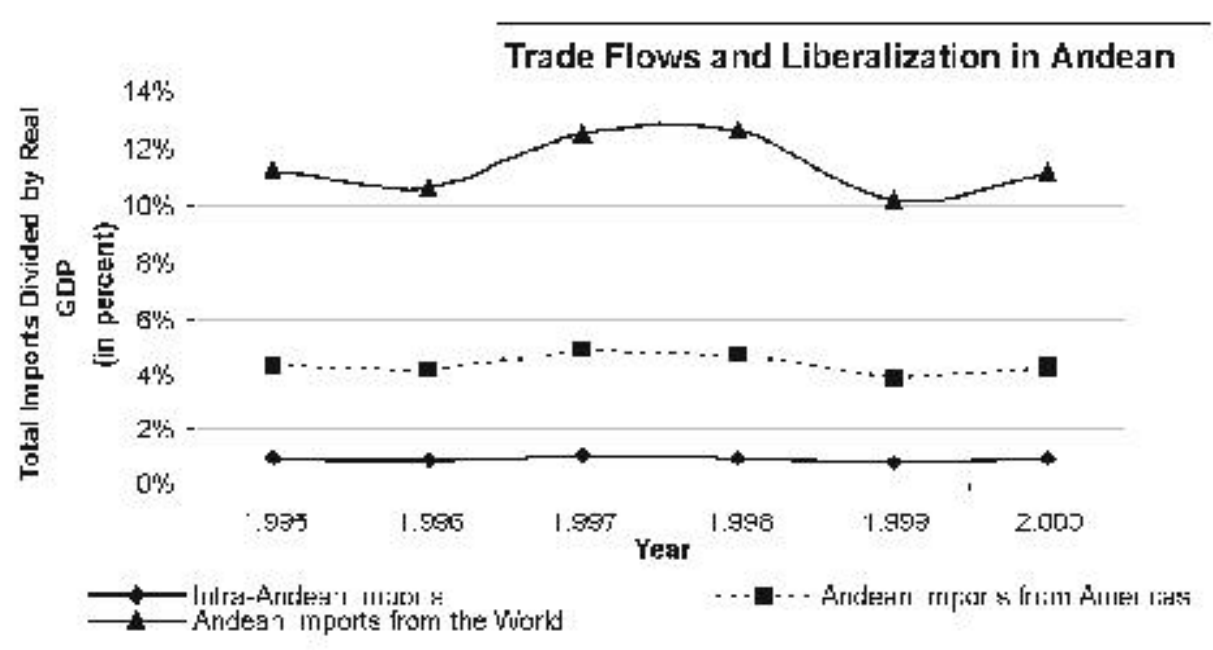

Figure No. 2

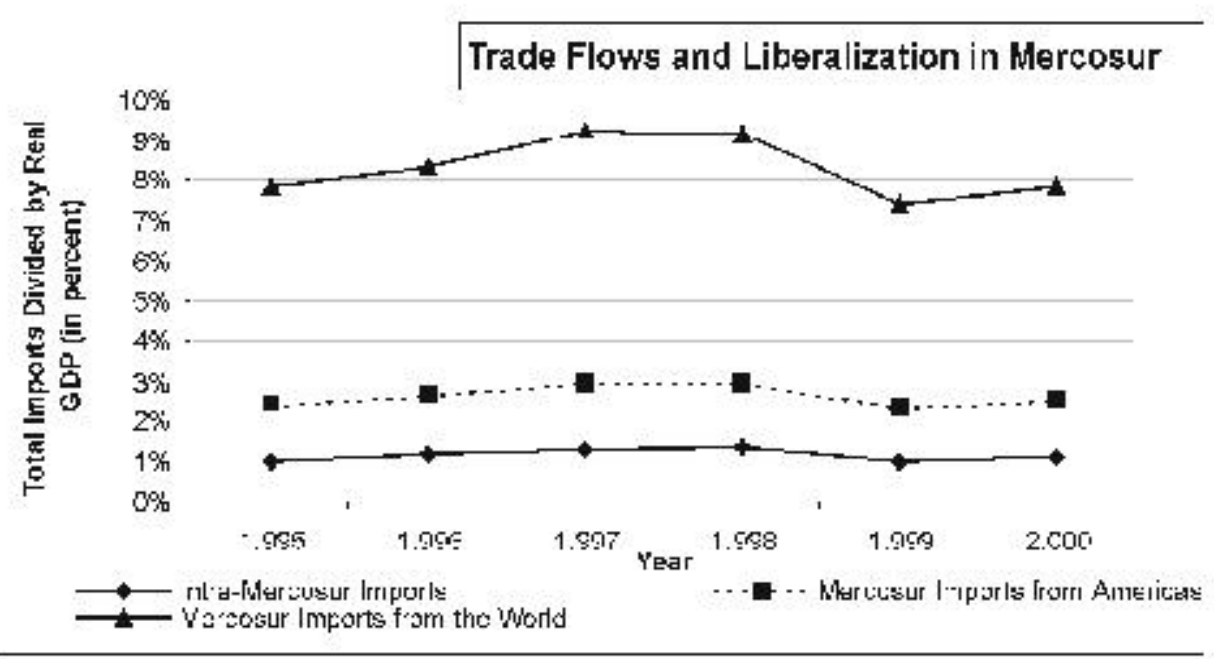




\section{Figure No. 3}

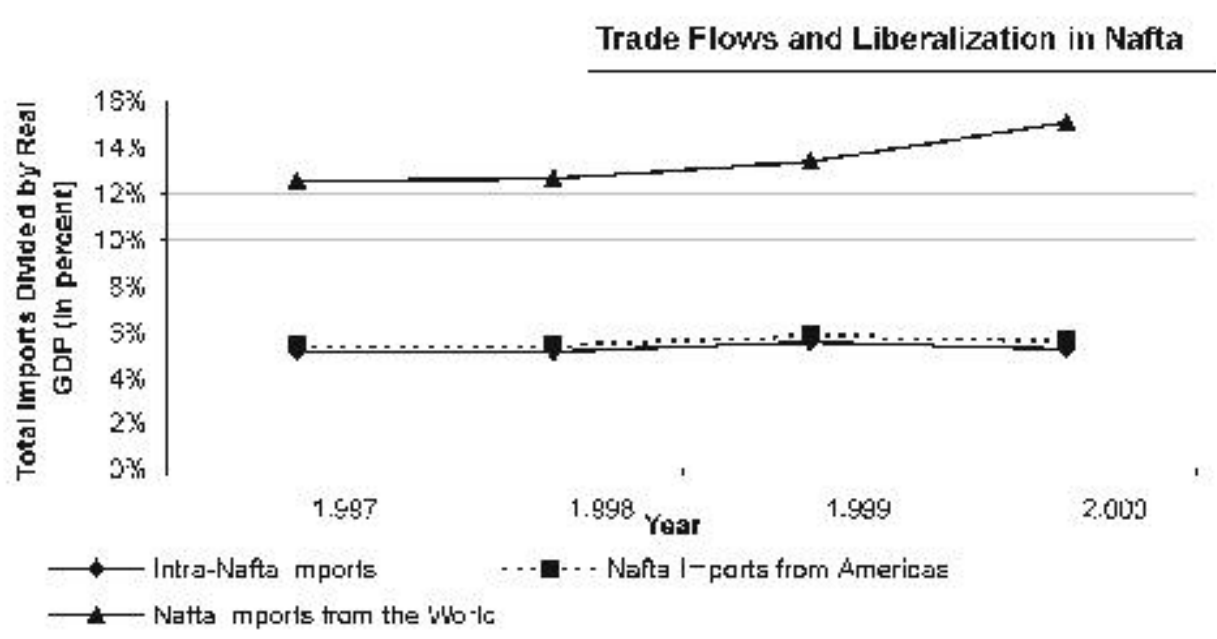

Figure 4 shows intra-region, intra-Americas imports, and imports from the world for the ALALC - ALADI where liberalization has pushed trade flows up. Within this region, there is a significant convergence which can be considered a result of deeper liberalization.

Figure No. 4

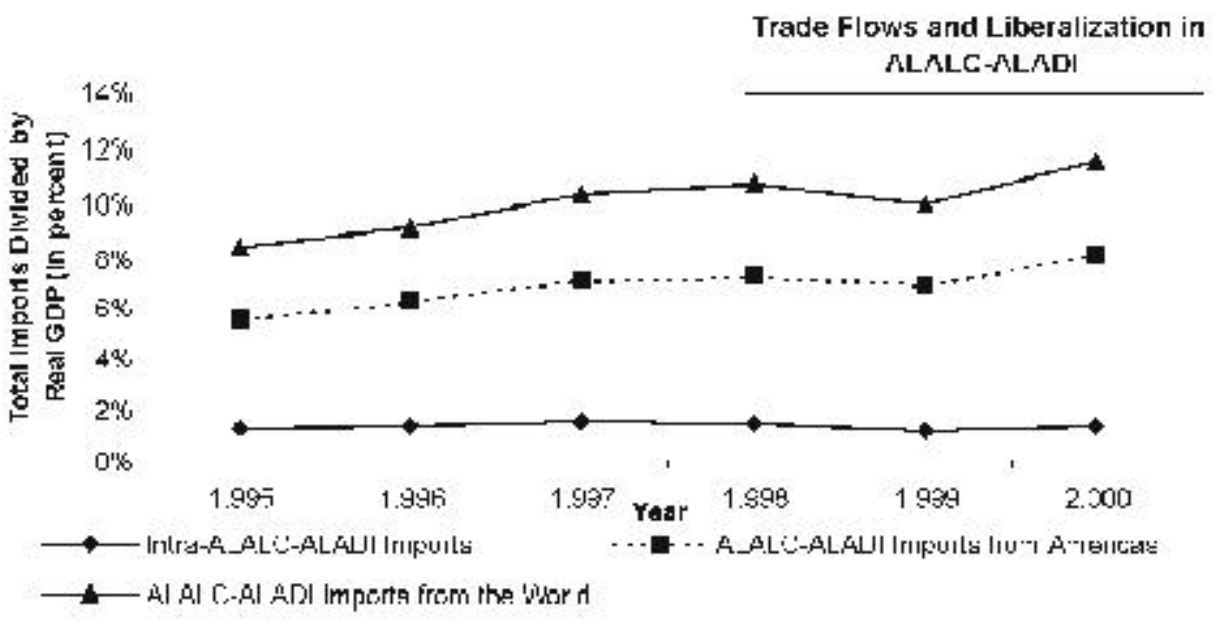




\section{Income Dispersion.}

Additional evidence which helps explaining why there is income convergence or divergence can be found by computing income dispersion within the different free trade areas. Income dispersion is measured as the annual cross-country standard deviations of log per capita incomes.

\section{Figure No. 5}

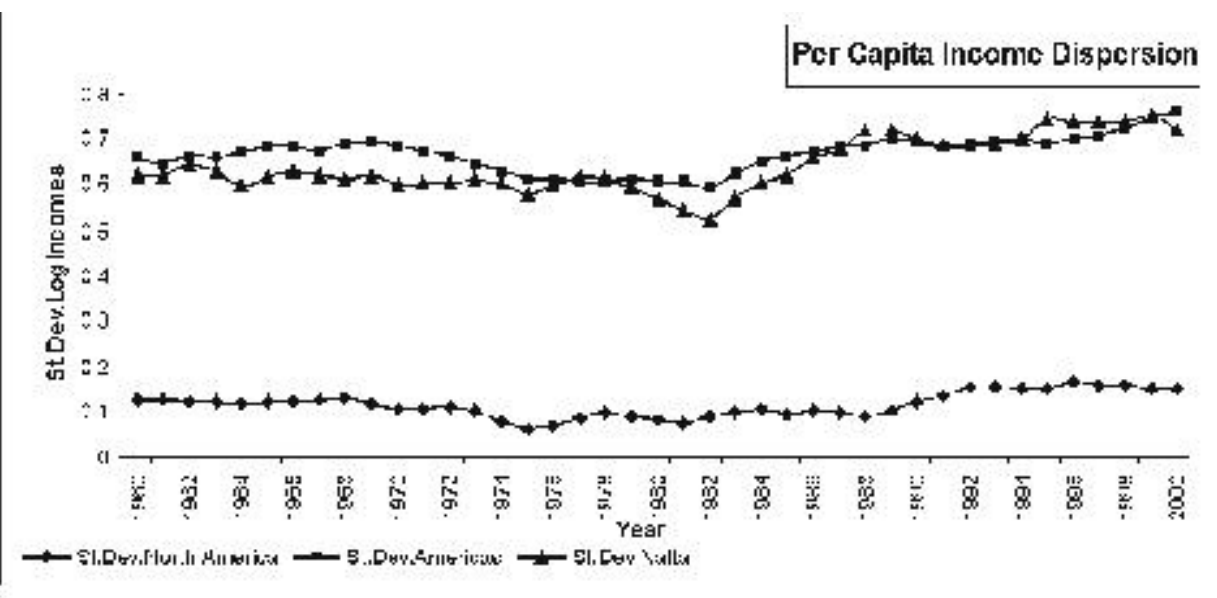

Figure No. 6

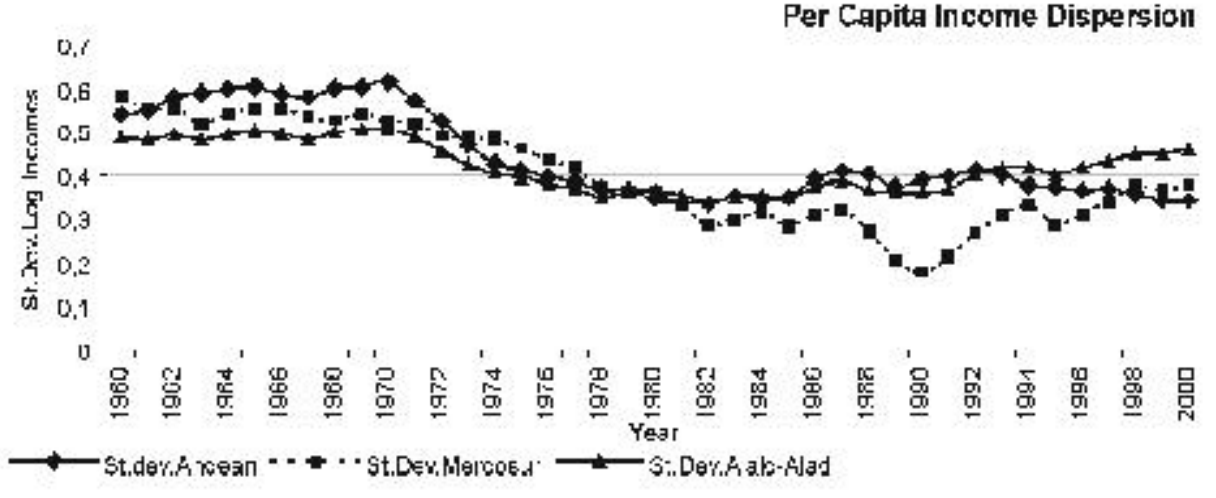


Figure 5 shows income dispersion for those areas including the U.S. Figure 6 shows it for the remaining ones. For all the areas in Figure 5 -The Americas, NAFTA, and North America-, income dispersion increases noticeably. The opposite happens for ALALC - ALADI, Andean, and Mercosur. Particularly in The Americas, income dispersion has gone from .65 to .76 in the period 1960 - 2000. The empirical evidence showing income divergence reflects this fact. On the other hand, in the ALALC ALADI, where there is evidence of convergence, its income dispersion decreases from .49 to .46 . These Figures provide additional evidence that trade has contributed to close the income gap in the ALALC - ALADI, but it has widened it in those areas including the U.S.

\section{CONCLUSIONS.}

In summary, not only the coefficient of income convergence is significant and positive for the ALALC - ALADI in the period after liberalization, but also the income dispersion has decreased and trade flows within the region have increased. All these results are in line with the findings of Ben-David (1993a) for the EEC. Based on them, it is possible to conclude that in the ALALC - ALADI case, there is empirical evidence that trade has contributed to close the income gap among the participating countries.

The opposite has occurred in The Americas and, in general, in all those areas including the U.S. They exhibit income divergence, instead, along with an increasing income dispersion. The question remains of why trade has not produced the same results in these free trade zones compared to the ALALC - ALADI and the EEC.

There are two possible explanations for that fact. The first one is that trade helps in closing the income gap when the countries that it involves are symmetric, as it is the case in the EEC and in the ALALC - ALADI. The inclusion of the U.S. in a free trade area seems to cause divergence due to the fact that this is, by far, a more developed country. The second explanation is that divergence is a consequence of unequal trade. Current trade agreements include clauses for free trade of manufactured products but limit exports of primary products, thus, these agreements favor exporters of the first ones, as it is the case of the U.S. Even Canada's exports have a large component of primary products although it is the second more developed country in the FTAA.

Based on the above discussion, what could we expect for the thirty-four countries participating in the FTAA in terms of income convergence? Even in the case of equal trade, where the agreement manages to conciliate the interests of developed and less developed countries, income convergence will, probably, not be one of the outcomes of this liberalization. The lack of symmetry in an area which gathers countries at very different stages of development, an asymmetry much more pronounced in the FTAA 
because it includes the largest economy in the world, prevent us from expecting income convergence even if this trade area becomes a successful one.

\section{Description of the data.}

GDP, and Population data come from the World Bank At a Glance Tables (www.worldbank.org).

Real GDP per capita at Constant Prices from Alan Heston, Robert Summers and Bettina Aten, Penn World Table Version 6.1, Center for International Comparisons at the University of Pennsylvania (CICUP), October 2002 (http://pwt.econ.upenn.edu/).

Trade flows data for Mercosur, CAN, and ALADI countries come from ALADI (www.aladi.org) and for NAFTA countries from FTAA (http://alca-ftaa.iadb.org/esp/ ngmadb s.htm). 


\section{References.}

Barro, J. and X. Sala-i-Martin (1992) "Convergence". The Journal of Political Economy 100, Issue 2. 223-251.

Baumol, W. (1986) "Productivity Growth, Convergence, and Welfare: What the Long-Run Data Show". The American Economic Review. 76, Issue 5. 1072-1085.

Baumol, W. And E.N. Wolff (1988) "Productivity Growth, Convergence, and Welfare: Reply". The AmericanEconomic Review. 78, Issue 5. 1072-1085.

Ben-David, D. (1993a) "Equalizing exchange: Trade Liberalization and Income Convergence". Quarterly Journal of Economics 108, Issue 3. 653-679.

Ben-David, D. (1993b) "Income disparity among countries and the effects of freer trade", in Economic Growth and the Structure of Long Run Development, Luigi Pasinetti and Robert Solow, Eds. International Economic Association London: Macmillan.

Ben-David, D. (1996) "Trade and Convergence Among Countries". Journal of International Economics 40. 279298.

De Long, J.B. (1988) "Productivity Growth, Convergence, and Welfare: Comment". The American Economic Review 78, Issue 5. 1138-1154.

Emmanuel, A. (1969) Unequal Exchange: A Study of the Imperialism of Trade. Paris: Librairie Francois Maspero.

Greene, W.H. (1997) Econometric Analysis. 3 $3^{\text {rd }}$ Ed. New Jersey: Prentice Hall. 1075 p.

Krugman, P. and M. Obstfeld. (1997) International Economics. Theory and Policy. $4^{\text {th }}$. Ed. Reading, Massachusetts: Addison-Wesley. $766 \mathrm{p}$.

Mankiw, N.G., D. Romer, and D.N.Weil (1992) "A Contribution to the Empirics of Economic Growth”. The Quarterly Journal of Economics 107, Issue 2. 407-437.

Samuelson, P. (1948) "International Trade and the Equalization of Factor Prices". Economic Journal 58. 163 184.

Samuelson, P. (1949) "International Factor Price Equalization Once Again". Economic Journal 59. 181 -196.

Slaughter, M. (1997) "Per Capita Income Convergence and the Role of International Trade". TheAmericanEconomic Review 87, Issue 2. Papers and Proceedings of the Hundred and Fourth Annual Meeting of the American Economic Association. 194-199.

Slaughter, M. (1998) "International Trade and Per Capita Income Convergence: A Difference-in-Differences Analysis". National Bureau of Economic Research Working Paper 6557. http://www.nber.org/papers/w6657 (May, 1998).

Solow, R. (1956) "A Contribution to the Theory of Economic Growth". Quarterly Journal of Economics. LXX 65-94.

Wong, K. (1995) International Trade in Goods and Factor Mobility. Cambridge, Massachusetts: The MIT press. 